\title{
Isolation of viral haemorrhagic septicaemia virus from Atlantic herring Clupea harengus from the English Channel
}

\author{
P. F. Dixon ${ }^{1, *}$, S. Feist ${ }^{1}$, E. Kehoe ${ }^{1}$, L. Parry ${ }^{2}$, D. M. Stone ${ }^{1}$, K. Way ${ }^{1}$ \\ ${ }^{1}$ Centre for Environment, Fisheries and Aquaculture Science, Fish Diseases Laboratory, Weymouth, Dorset DT4 8UB, \\ United Kingdom \\ ${ }^{2}$ University of Wales College of Cardiff, Cardiff CF1 3TE, United Kingdom
}

\begin{abstract}
Viral haemorrhagic septicaemia virus (VHSV) was isolated from apparently healthy Atlantic herring Clupea harengus from the English Channel. The virus was isolated in bluegill fibroblast (BF-2) cells but not epithelioma papulosum cyprini (EPC) cells; however, the virus was passaged from BF-2 to EPC cells. The identity of the virus was confirmed by an enzyme-linked immunosorbent assay and by a reverse transcriptase-polymerase chain reaction (RT-PCR). The virus was classified as a member of genogroup III of VHSV, which comprises many European fresh water and marine VHSV isolates. Sequence comparisons of the RT-PCR products showed that the herring isolate was closely related (99.1\% nucleotide similarity) to a VHSV isolate from Atlantic cod Gadus morhua; both of those isolates were avirulent for rainbow trout Oncorhynchus mykiss by bath infection. Circumstantial evidence is presented which suggests that VHSV from herring could have been the source of VHS disease in rainbow trout in Denmark.
\end{abstract}

KEY WORDS: VHSV $\cdot$ Atlantic herring $\cdot$ Clupea harengus $\cdot \mathrm{PCR}$

\section{INTRODUCTION}

A rhabdovirus was isolated in 1979 from Atlantic cod Gadus morhua, caught from Danish coastal waters, exhibiting signs of the 'ulcus syndrome' (Jensen et al. 1979). The virus was later identified as viral haemorrhagic septicaemia virus (VHSV) by Jørgensen \& Olesen (1987), and those authors considered that the virus was likely to be a contaminant (either of the cod surface, or of the cell cultures) derived from a freshwater source. However, since then, VHSV has been isolated from farmed turbot Scophthalmus maximus and wild cod and haddock Melanogrammus aeglefinus from European waters (Schlotfeldt et al. 1991, Ross et al. 1994, Smail 1995, D. Smail cited by Munro 1996), and from chinook Oncorhynchus tshawytscha and coho salmon O. kisutch, Pacific cod G. macrocephalus and Pacific herring Clupea harengus pallasi from the Pacific coast of North America (Hopper 1989, Brunson

·E-mail: p.f.dixon@cefas.co.uk et al. 1989, Meyers et al. 1991, 1994, Traxler \& Kieser 1994). [Note: The scientific names of fish follow the recommendations of Wheeler (1992).]

As a result of this accumulated data, there is now no reason to believe that the VHSV isolated from Atlantic cod with the ulcus syndrome was a contaminant. Furthermore, these isolations of VHSV from fish in the marine environment have led to a re-evaluation of the epidemiology of VHSV, which had been considered as primarily a pathogen of salmonids (mainly rainbow trout Oncorhynchus mykiss) in freshwater. It has been suggested that VHSV in mainland Europe originated from a marine source and not vice versa (Meyers \& Winton 1995).

This laboratory has undertaken a programme of marine fish disease monitoring for many years, recording the incidence and prevalence of external disease conditions and liver pathology in dab Limanda limanda and flounder Pleuronectes flesus according to international guidelines (Bucke et al. 1996). Although dab is the target species for monitoring purposes, other 
fish species, especially those of commercial importance, are also examined for the presence of significant diseases. In particular, Atlantic herring Clupea harengus are examined for the presence of Ichthyophonus, a lethal protistan pathogen, and Atlantic cod and other gadoids are examnned for pseudobranch 'tumours', parasites and ulcerative lesions. As the latter may be associated with VHSV, tissue samples were taken from certain of those other species, particularly gadoids, on a recent survey and were later tested for the presence of viruses by isolation in cell culture using a procedure recommended by the Commission of the European Union for the isolation of VHSV. We report here the isolation of VHSV from Atlantic herring and molecular comparisons of the virus with other VHSV isolates.

\section{MATERIALS AND METHODS}

Fish sampling. Fish were caught at 10 sampling areas in UK coastal waters (Fig. 1) during January and February 1996, using a Granton trawl or a beam trawl (the latter in Rye Bay only); between 1 and 4 stations were trawled at each sampling area. The fish taken for sampling are listed in Table 1. Each species was sampled separately; the same instruments were used to sample one species from a station, but were changed for a different species or for a different station. Portions of liver, kidney, spleen, heart and brain were taken from each fish. The tissues of the first 10 fish of one species at a station were collected in individual containers; if there were more than 10 fish of that species at the station, the tissues of the 11th fish were added to the first container, the tissues of the 12 th fish were added to the second container and so on up to a maximum of 5 fish per pool. Maintenance medium (MM) (Glasgow modification of Eagle's medium supplemented with $2 \%$ foetal calf serum) containing a high level of antibiotics $\left(1000 \mathrm{IU} \mathrm{m}^{-1}\right.$ penicillin $\mathrm{G}$ [sodium salt] and $1 \mathrm{mg} \mathrm{ml}^{-1}$ streptomycin sulphate) (MM-HLA) was added in the approximate ratio of 10:1 (MM-HLA:tissue). The samples were then blast frozen at $-20^{\circ} \mathrm{C}$ and transported frozen to the laboratory at the end of the sampling period.

Sample processing. At the laboratory the samples were thawed and processed by the method stipulated by the Commission of the European Union for detecting VHSV (Anonymous 1992). This was done in a microbiological safety cabinet so that in the event of virus being isolated, the possibility of laboratory contamination of the samples could be discounted. The processing method was as follows. The samples were ground to a paste using a mortar, pestle and sterile sand, clarified at $2000 \times g$ for $15 \mathrm{~min}$ at $4^{\circ} \mathrm{C}$, then exposed to the antibiotics in the MM-HLA for $4 \mathrm{~h}$ at $15^{\circ} \mathrm{C}$. Final dilutions of $1: 100$ and $1: 1000$ were inoculated onto bluegill fibroblast $(\mathrm{BF}-2)$ and epithelioma papulosum cyprini (EPC) cells, which were incubated at $15^{\circ} \mathrm{C}$. The stock tissue extracts were then stored at $-70^{\circ} \mathrm{C}$. The cells were observed daily for cytopathic effect (CPE). If no CPE was observed after $7 \mathrm{~d}$, the cell cultures were frozen at $-20^{\circ} \mathrm{C}$, thawed, and the medium from each cell line was diluted to $1: 10$ (final) and inoculated onto fresh homologous cell cultures.

Virus identification. When CPE was observed in cell cultures inoculated with fish extracts, supernatant fluids were tested in enzyme-linked immunosorbent assays (ELISAs) for birnaviruses (Dixon \& Hill 1983) (as they are ubiquitous in the marine environment) and VHSV (Way \& Dixon 1988, Way 1996). The VHSV ELISA was also carried out directly on the herring

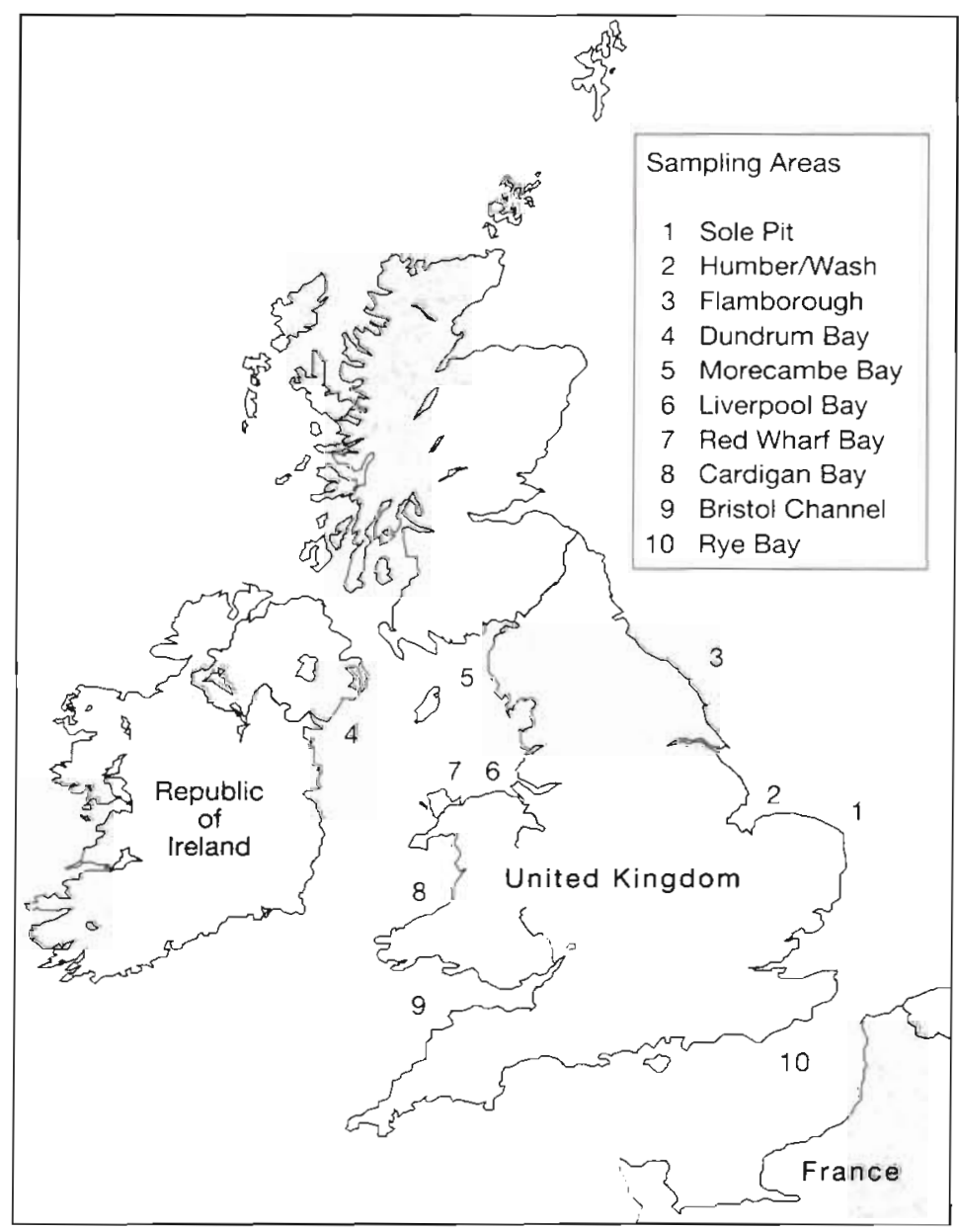

Fig. 1. Areas where marine fish were collected for viral examination 
Table 1. Fish sampled for virus isolation

\begin{tabular}{|c|c|c|c|c|c|}
\hline Station & Sampling area ${ }^{\circ}$ & Location & Fish sampled & Species & $\begin{array}{c}\text { Number } \\
\text { tested }\end{array}$ \\
\hline 1 & 1 Sole Pit & $53^{\circ} 38.81^{\prime} \mathrm{N}, 01^{\circ} 32.90^{\prime} \mathrm{E}$ & Cod & Gadus morhua & 3 \\
\hline 2 & 1 Sole Pit & $53^{\circ} 48.24^{\prime} \mathrm{N}, 01^{\circ} 30.26^{\prime} \mathrm{E}$ & Cod & G. morhua & 3 \\
\hline 4 & 2 Humber/Wash & $53^{\circ} 18.08^{\prime} \mathrm{N}, 00^{\circ} 26.71^{\prime} \mathrm{E}$ & Cod & G. morhua & 24 \\
\hline 5 & 2 Humber/Wash & $53^{\circ} 07.52^{\prime} \mathrm{N}, 00^{\circ} 33.77^{\prime} \mathrm{E}$ & Cod & G. morhua & 4 \\
\hline 6 & 2 Humber/Wash & $53^{\circ} 16.27^{\prime} \mathrm{N}, 00^{\circ} 31.19^{\prime} \mathrm{E}$ & Cod & G. morhua & 19 \\
\hline 7 & 2 Humber/Wash & $53^{\circ} 17.21^{\prime} \mathrm{N}, 00^{\circ} 26.52^{\prime} \mathrm{E}$ & Cod & G. morhua & 2 \\
\hline 22 & 3 Flamborough & $54^{\circ} 14.03^{\prime} \mathrm{N}, 00^{\circ} 31.15^{\prime} \mathrm{E}$ & Cod & G. morhua & 1 \\
\hline 23 & 3 Flamborough & $54^{\circ} 12.52^{\prime} \mathrm{N}, 00^{\circ} 37.45^{\prime} \mathrm{E}$ & Cod & G. morhua & 3 \\
\hline 23 & 3 Flamborough & $54^{\circ} 12.52^{\prime} \mathrm{N}, 00^{\circ} 37.45^{\prime} \mathrm{E}$ & Turbot & Scophthalmus maximus & 1 \\
\hline 25 & 3 Flamborough & $54^{\circ} 14.84^{\prime} \mathrm{N}, 00^{\circ} 34.39^{\prime} \mathrm{E}$ & Cod & G. morhua & 2 \\
\hline 26 & 4 Dundrum Bay & $54^{\circ} 08.54^{\prime} \mathrm{N}, 05^{\circ} 47.58^{\prime} \mathrm{W}$ & Cod & G. morhua & 12 \\
\hline 28 & 4 Dundrum Bay & $54^{\circ} 11.76^{\prime} \mathrm{N}, 05^{\circ} 47.27^{\prime} \mathrm{W}$ & Cod & G. morhua & 11 \\
\hline 29 & 4 Dundrum Bay & $54^{\circ} 08.42^{\prime} \mathrm{N}, 05^{\circ} 47.74^{\prime} \mathrm{W}$ & Cod & G. morhua & 11 \\
\hline 30 & 5 Morecambe Bay & $54^{\circ} 04.31^{\prime} \mathrm{N}, 03^{\circ} 25.94^{\prime} \mathrm{W}$ & Cod & G. morhua & 3 \\
\hline 30 & 5 Morecambe Bay & $54^{\circ} 04.31^{\prime} \mathrm{N}, 03^{\circ} 25.94^{\prime} \mathrm{W}$ & Whiting & Merlangius merlangus & 10 \\
\hline 31 & 5 Morecambe Bay & $54^{\circ} 03.69^{\prime} \mathrm{N}, 03^{\circ} 21.54^{\prime} \mathrm{W}$ & Cod & G. morhua & 5 \\
\hline 31 & 5 Morecambe Bay & $54^{\circ} 03.69^{\prime} \mathrm{N}, 03^{\circ} 21.54^{\prime} \mathrm{W}$ & Whiting & M. merlangus & 10 \\
\hline 32 & 5 Morecambe Bay & $54^{\circ} 03.86^{\prime} \mathrm{N}, 03^{\circ} 22.66^{\prime} \mathrm{W}$ & Cod & G. morhua & 1 \\
\hline 33 & 6 Liverpool Bay & $53^{\circ} 57.96^{\prime} \mathrm{N}, 03^{\circ} 23.55^{\circ} \mathrm{W}$ & Cod & G. morhua & 10 \\
\hline 34 & 6 Liverpool Bay & $53^{\circ} 27.96^{\prime} \mathrm{N}, 03^{\circ} 23.21^{\prime} \mathrm{W}$ & Cod & G. morhua & 10 \\
\hline 36 & 6 Liverpool Bay & $53^{\circ} 28.67^{\prime} \mathrm{N}, 03^{\circ} 44.07^{\prime} \mathrm{W}$ & Cod & G. morhua & 7 \\
\hline 36 & 6 Liverpool Bay & $53^{\circ} 28.67^{\prime} \mathrm{N}, 03^{\circ} 44.07^{\prime} \mathrm{W}$ & Poor-cod & Trisopterus minutus & 3 \\
\hline 37 & 7 Red Wharf Bay & $53^{\circ} 21.82^{\prime} \mathrm{N}, 04^{\circ} 10.38^{\prime} \mathrm{W}$ & Cod & G. morhua & 20 \\
\hline 39 & 8 Cardigan Bay & $52^{\circ} 15.25^{\prime} \mathrm{N}, 04^{\circ} 20.66^{\prime} \mathrm{W}$ & Whiting & M. merlangus & 20 \\
\hline 40 & 8 Cardigan Bay & $52^{\circ} 21.83^{\prime} \mathrm{N}, 04^{\circ} 21.67^{\prime} \mathrm{W}$ & Whiting & M. merlangus & 18 \\
\hline 41 & 8 Cardigan Bay & $52^{\circ} 14.51^{\prime} \mathrm{N}, 04^{\circ} 22.71^{\prime} \mathrm{W}$ & Whiting & $M$ merlangus & 12 \\
\hline 42 & 9 Bristol Channel & $51^{\circ} 33.00^{\prime} \mathrm{N}, 04^{\circ} 42.33^{\prime} \mathrm{W}$ & Cod & G. morhua & 1 \\
\hline 42 & 9 Bristol Channel & $51^{\circ} 33.00^{\prime} \mathrm{N}, 04^{\circ} 42.33^{\prime} \mathrm{W}$ & Haddock & Melanogrammus aeglefinus & 1 \\
\hline 42 & 9 Bristol Channel & $51^{\circ} 33.00^{\prime} \mathrm{N}, 04^{\circ} 42.33^{\prime} \mathrm{W}$ & Whiting & M. merlangus & 50 \\
\hline 43 & 10 Rye Bay & $50^{\circ} 51.71^{\prime} \mathrm{N}, 00^{\circ} 47.50^{\prime} \mathrm{E}$ & Cod & G. morhua & 15 \\
\hline 43 & 10 Rye Bay & $50^{\circ} 51.71^{\prime} \mathrm{N}, 00^{\circ} 47.50^{\prime} \mathrm{E}$ & Herring & Clupea harengus & 50 \\
\hline 49 & 10 Rye Bay & $50^{\circ} 49.21^{\prime} \mathrm{N}, 00^{\circ} 52.04^{\prime} \mathrm{E}$ & $\operatorname{Cod}$ & G. morhua & 1 \\
\hline
\end{tabular}

extract. Immunoassay plates were coated with immunoglobulins against the viruses, and plates were blocked with fish skin gelatin. Cell culture supernatants or fish extracts were diluted to $1: 4,1: 8$ and $1: 16$ in phosphate buffered saline containing $0.02 \%$ Tween 20 and $1 \%$ Nonidet $\mathrm{P} 40$; duplicate samples were tested. Non-infected BF-2 cell cultures, or herring extracts from a previous sampling occasion, negative for VHSV by cell culture isolation, were used as negative controls. Monoclonal antibody or immunoglobulin $G$ from polyclonal sera against the viruses had been biotinylated, the enzyme label was a conjugate of ExtrAvidin and horseradish peroxidase (Sigma) (Way 1996) and the substrate was 3,3',5,5'-tetramethylbenzidine (Sigma). After stopping the enzyme-substrate reaction with $2 \mathrm{M}$ sulphuric acid, the absorbance of the reaction product was read on an EIA reader (MR7000, Dynatech) at $450 \mathrm{~nm}$. A sample was positive if it had an absorbance 5 times that of the appropriate negative control.

Reverse transcriptase-polymerase chain reaction (RT-PCR). The RNA extraction and RT-PCR for VHSV was carried out as described by Strømmen \& Stone (1997) on cell culture harvests and on duplicate pools of herring extracts. The method uses a degenerate primer set which amplifies a 360 nucleotide sequence of the glycoprotein gene (nucleotides 361-720, amino acid residues 121-240). Infectious hematopoietic necrosis virus (IHNV), provided by D. Amend, Seattle, and spring viraemia of carp virus (SVCV) provided by N. Fijan, Zagreb, were used as negative control viruses.

DNA sequencing. PCR products were ligated into pSK-Bluescript (Stratagene) as described previously (Stone et al. 1997). The nucleotide sequence of the inserts was determined by the dideoxynucleotide chain termination method (Sanger et al. 1977) using the M13-20 and reverse primers (Stratagene). Sequence alignments and phylogenetic trees were constructed based on the Higgins and Sharp algorithm (Higgins \& Sharp 1988) using DNASIS sequence analysis software (Hitachi Software Engineering America Ltd). The origins of VHSV isolates used for sequence comparisons are given in Table 2 
Table 2. Origins of the VHSV isolates

\begin{tabular}{|c|c|c|c|c|}
\hline Isolate & Host & Habitat & Source of isolate & Reported in: \\
\hline $96-43$ & $\begin{array}{l}\text { Herring } \\
\text { Clupea harengus }\end{array}$ & $\begin{array}{l}\text { Europe (England), } \\
\text { marine }\end{array}$ & Authors & This study \\
\hline VHSV F1 & $\begin{array}{l}\text { Rainbow trout } \\
\text { Oncorhynchus mykiss }\end{array}$ & $\begin{array}{l}\text { Europe (Denmark), } \\
\text { freshwater }\end{array}$ & $\begin{array}{l}\text { P. E. V. Jørgensen, } \\
\text { Arhus }\end{array}$ & Jensen (1965) \\
\hline Hededam $(\mathrm{He})$ & $\begin{array}{l}\text { Rainbow trout } \\
\text { O. mykiss }\end{array}$ & $\begin{array}{l}\text { Europe (Denmark), } \\
\text { freshwater }\end{array}$ & J. Winton, Seattle & Jorgensen (1980) \\
\hline $814 / 94$ & $\begin{array}{l}\text { Turbot } \\
\text { Scophthalmus maximus }\end{array}$ & $\begin{array}{l}\text { Europe (Scotland), } \\
\text { marine }\end{array}$ & D. Smail, Aberdeen & Ross et al. (1994) \\
\hline Cod Rhabdo & $\begin{array}{l}\text { Atlantic cod } \\
\text { Gadus morhua }\end{array}$ & $\begin{array}{l}\text { Europe (Denmark), } \\
\text { marine }\end{array}$ & N. Olesen, Århus & Jensen et al. (1979) \\
\hline NA-1 (Makah) & $\begin{array}{l}\text { Coho salmon } \\
\text { O. kisutch }\end{array}$ & $\begin{array}{l}\text { N. America, } \\
\text { marine }\end{array}$ & J. Winton, Seattle & $\begin{array}{l}\text { Brunson et al. (1989) } \\
\text { Batts et al. (1993) }\end{array}$ \\
\hline $3592-B$ & $\begin{array}{l}\text { Rainbow trout } \\
\text { O. mykiss }\end{array}$ & $\begin{array}{l}\text { Europe (Denmark), freshwater } \\
\text { freshwater }\end{array}$ & N. Lorenzen, Århus & Lorenzen et al. (1993) \\
\hline
\end{tabular}

Virus growth and titration. VHSV was grown and titrated in BF-2 or EPC cells at $15^{\circ} \mathrm{C}$ as described by Hill et al. (1975) except that the plaques were stained with $0.1 \%$ aqueous crystal violet as described by Dixon \& Hill (1983).

Fish infection. Rainbow trout (13 wk old, ca $4.8 \mathrm{~g}$ ) were purchased from a commercial source, maintained at a density of 100 fish per tank of $50 \mathrm{l}$ dechlorinated tap water at $11^{\circ} \mathrm{C}$ in a flow-through system and were fed a maintenance diet. The fish were exposed to $10^{4}$ plaque forming units (PFU) of virus $\mathrm{ml}^{-1}$ for $1 \mathrm{~h}$ with no water flow, after which the water flow was resumed. Viruses compared were the Atlantic herring VHSV isolate, VHSV isolate 3592-B (known to cause mortality in rainbow trout) and VHSV isolate 'cod rhabdo' (Table 2). Mortalities were recorded and dead fish removed from the tanks on a daily basis for $28 \mathrm{~d}$ postinfection. Dead fish were tested for the presence of virus as described above, and the identity of virus isolated in cell culture was determined using the VHSV ELISA.

\section{RESULTS}

\section{Isolation and identification of VHSV}

The only CPE observed was in BF-2 cell cultures inoculated with extracts of herring caught at Rye Bay, Stn 43 (Table 1). CPE was observed in 3 of the 10 pools of fish (nos. 8, 9 and 10) 4 d post-inoculation; no other pools showed CPE by $7 \mathrm{~d}$ post-inoculation. CPE developed in 1 additional pool (no. 5) 4 d after passage. Supernatants from cell cultures showing CPE were positive for VHSV (Table 3) and negative for birnavirus in the respective ELISAs; the isolate was desig- nated 96-43. The VHSV ELISA carried out directly on herring extracts did not reveal the presence of virus antigen, as any positive reactions were masked by the high level of non-specific binding caused by the extracts (Table 3). Negative control herring extracts produced high absorbance readings which were similar to those produced by the test samples.

No CPE was observed in the EPC cells inoculated with the herring extracts. As this was unexpected, the herring extracts were thawed from $-70^{\circ} \mathrm{C}$ and the procedure for isolation of virus was repeated. Again, no

Table 3. VHSV ELISA absorbance values of BF-2 cell cultures showing CPE after inoculation with extracts from Atlantic herring caught at Stn 43 (Rye Bay), and ELISA absorbance values of the original herring extracts

\begin{tabular}{|c|c|c|c|}
\hline Sample & Origin & Dilution & $\begin{array}{c}\text { Absorbance } \\
(450 \mathrm{~nm})\end{array}$ \\
\hline Pool 1 & BF-2 cells & $1: 16$ & 0.334 \\
\hline Pool 5 & BF-2 cells & $1: 16$ & 0.337 \\
\hline Pool 6 & BF-2 cells & $1: 16$ & 0.315 \\
\hline Pool 8 & BF -2 cells & $1: 16$ & 0.290 \\
\hline Pool 9 & BF-2 cells & $1: 16$ & 0.350 \\
\hline Pool 10 & BF -2 cells & $1: 16$ & 0.352 \\
\hline Negative control & BF-2 cells & $1: 16$ & 0.010 \\
\hline $\begin{array}{l}\text { Positive control } \\
\text { (VHSV F1) }\end{array}$ & $B F-2$ cells & $1: 16$ & 0.272 \\
\hline Pool 7 & Herring extract & $1: 4^{\circ}$ & 0.263 \\
\hline Pool 8 & Herring extract & $1: 4^{\circ}$ & 0.140 \\
\hline Pool 9 & Herring extract & $1: 4^{\mathrm{d}}$ & 0.214 \\
\hline Pool 10 & Herring extract & $1: 4^{\circ}$ & 0.172 \\
\hline Negative control & Herring extract & $1: 4$ & 0.247 \\
\hline Negative control & Herring extract & $1: 4$ & 0.257 \\
\hline Negative control & Herring extract & $1: 4$ & 0.222 \\
\hline Positive control & BF-2 cells & $1: 16$ & 0.293 \\
\hline \multicolumn{4}{|c|}{$\begin{array}{l}\text { 'Absorbance values of the } 1: 8 \text { and } 1: 16 \text { dilutions were } \\
\text { lower than those of the equivalent dilution of herring } \\
\text { extract negative controls }\end{array}$} \\
\hline
\end{tabular}


CPE was observed in the EPC cells. CPE in BF-2 cells was again observed in pools 8 and 9 (the latter only after passage). In addition, CPE was observed after passage in pools 1 and 6 , which had been negative for virus on the initial isolation attempt. The presence of VHSV in cell cultures showing CPE was confirmed by the ELISA (Table 3).

The virus harvested from the $\mathrm{BF}-2$ cells (first passage) was diluted to 1:100 and inoculated onto EPC cells. CPE developed in the cells and was confirmed as being caused by VHSV using the ELISA. The virus was passaged 3 times in and between BF-2 and EPC cells and titrated at each passage in both cell lines. After 3 passages in BF- 2 cells, the virus titre was $8 \times$ $10^{6} \mathrm{PFU} \mathrm{ml}^{-1}$ (titrated in BF-2 cells) and $4.2 \times 10^{5} \mathrm{PFU}$ $\mathrm{ml}^{-1}$ (titrated in EPC cells), whereas after 3 passages in EPC cells the virus titre was $2 \times 10^{7} \mathrm{PFU} \mathrm{\textrm {ml } ^ { - 1 }}$ (titrated in BF-2 cells) and $1.4 \times 10^{7} \mathrm{PFU} \mathrm{ml}^{-1}$ (titrated in EPC cells)

\section{RT-PCR}

RT-PCR was carried out on the supernatant fluids from BF-2 cells inoculated with pools 5, 8, 9 and 10 , and a product consistent with that expected from VHSV was observed (Fig. 2). Duplicate extractions and RT-PCR amplifications were done on the 10 pools of herring viscera thawed from $-70^{\circ} \mathrm{C}$. A product of the size expected from VHSV was obtained from all pools except pools 4 and 6 ; on both occasions those 2 pools produced smears over the region of the gel where the VHSV product was expected. Pools 2, 3, 5, 7 and 8 were positive for the product in both amplifications but pools 1,9 and 10 were only positive on one of the amplifications.

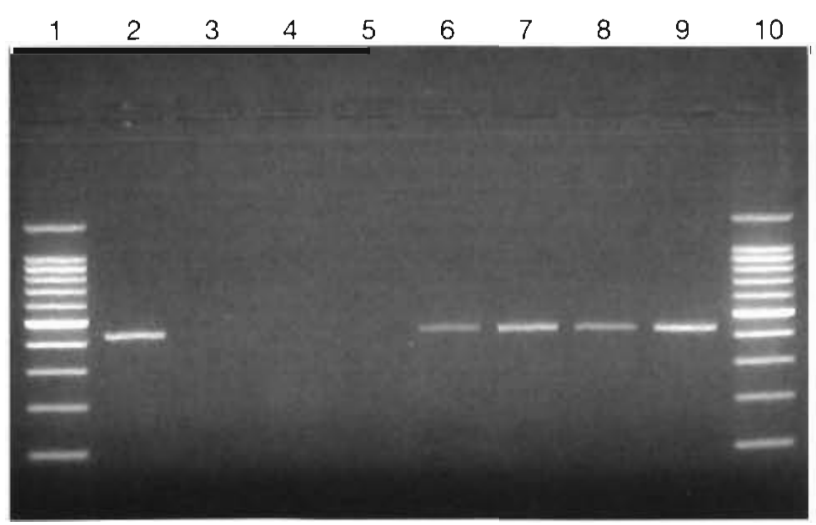

Fig. 2. Agarose gel of the PCR product from cell culture grown Atlantic herring VHSV isolate (96-43). Lanes 1 and 10 , 100 bp ladder; lane 2, VHSV F1; lane 3, IHNV; lane 4, SVCV; lane 5, negative control (water); lane 6, 96-43 pool 5; lane 7, 96-43 pool 8; lane 8, 96-43 pool 9; lane 9, 96-43 pool 10

\section{DNA sequence}

In order to confirm that the PCR products were derived from VHSV, the products from the pool 10 cell culture harvest and from 3 herring tissue extracts (pools 5,9 and 10) were sequenced and compared with VHSV F1 and other VHSV isolates (Fig. 3a). The nucleotide substitutions observed between the PCR products from 2 herring extracts (pools 5 and 10), and from the VHSV isolates 'cod rhabdo' and 814/96 (from turbot) were silent. Therefore, the deduced amino acid sequences were identical (Fig. 3b). The herring extracts, 96-43 from cell culture, 'cod rhabdo', 814/96 and Hededam isolates had 2 amino acid substitutions $\left(\mathrm{Asn}^{136} \rightarrow \mathrm{Asp}\right.$ and $\left.\mathrm{Ile}^{238} \rightarrow \mathrm{Val}\right)$ compared to the $\mathrm{F} 1$ isolate. Also, there was an further amino acid substitution (Thr ${ }^{212} \rightarrow$ Lys) between the herring extracts, 96-43 from cell culture, 'cod rhabdo' and 814/96 isolates, and the F1 and Hededam isolates.

The nucleotide sequences of the PCR products obtained directly from the 3 herring extract pools had $99.1 \%$ similarity to each other and to the PCR product from the virus isolated in cell culture (Fig. 4). They also shared $99.1 \%$ nucleatide sequence similarity to the VHSV isolate from Atlantic cod (cod rhabdo). The relationship of the herring isolate to the other VHSV isolates is also shown in Fig. 4.

\section{Virulence study}

The herring isolate did not cause any mortalities in the rainbow trout tested, whereas isolate 3592-B (from rainbow trout) killed $31 \%$ of the fish (confirmed by reisolation of the virus in cell culture). One fish of 100 infected with the 'cod rhabdo' isolate died, but virus was not re-isolated from it; no mortality was observed in non-exposed control fish.

\section{DISCUSSION}

VHSV was isolated from Atlantic herring from the English Channel (Rye Bay) showing no obvious external or internal signs of disease. Tissue extracts from 50 fish were tested, but because the same instruments were used to take the initial samples, and tissues were pooled, it was not possible to determine how many individual fish carried the virus. Potentially only one fish may have been infected with the virus and all the other pools of tissue could have been contaminated with virus from that fish. However, the number of pools of tissue positive for VHSV suggests that more than one fish was infected. The ELISA for VHSV was done directly on the tissue extracts in an attempt to deter- 


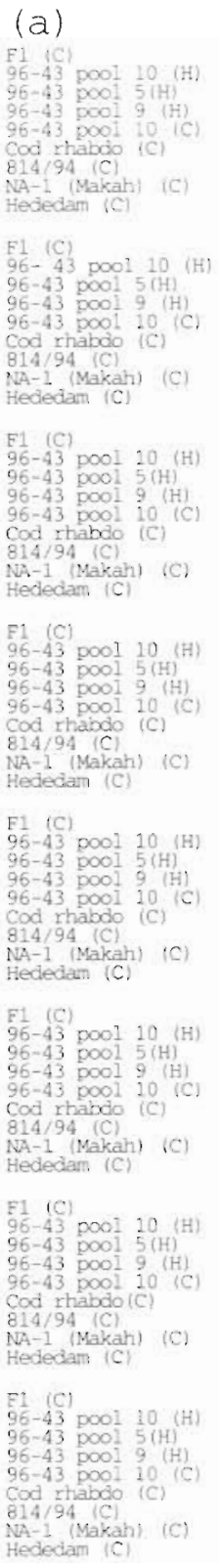

(b)

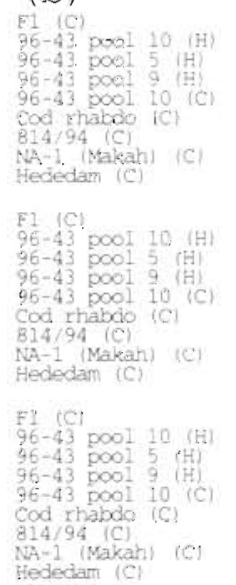

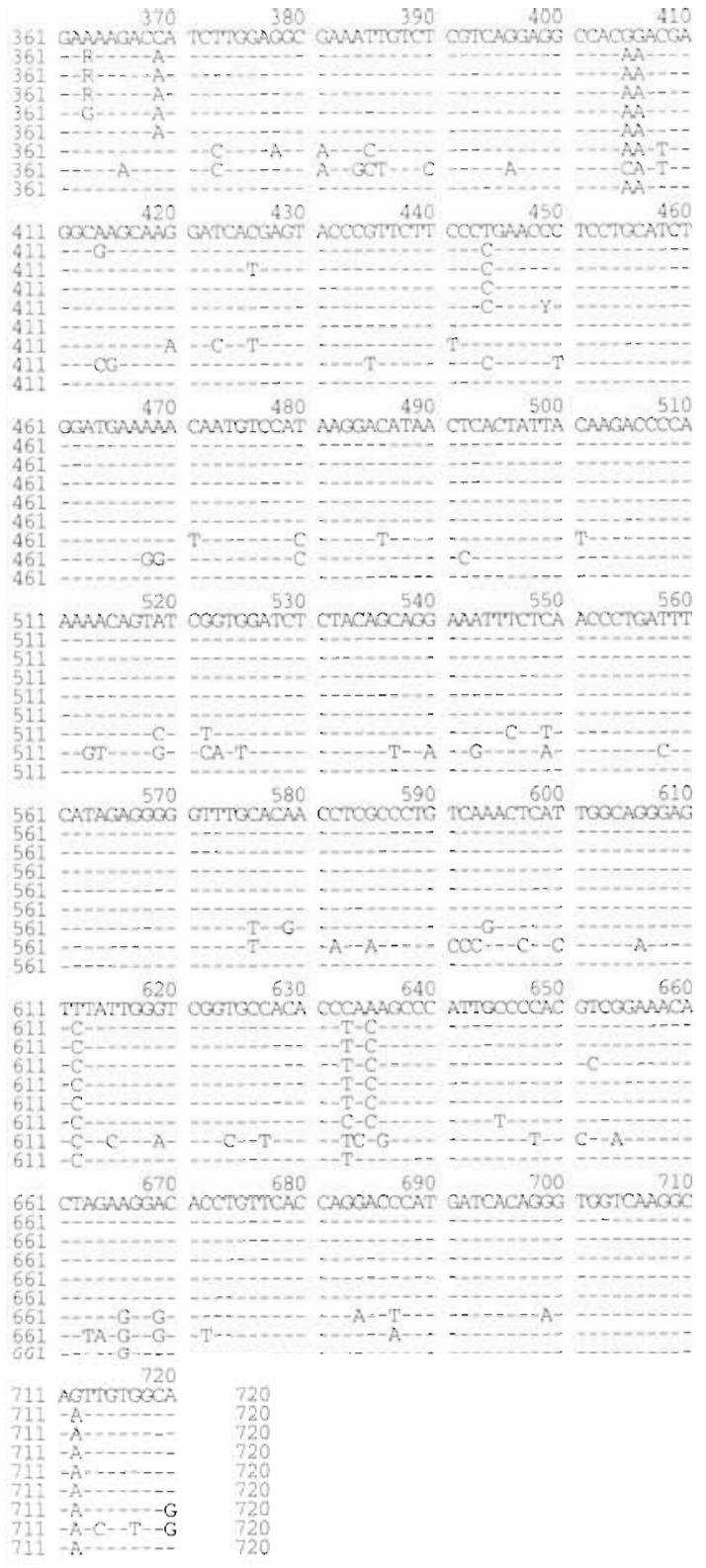

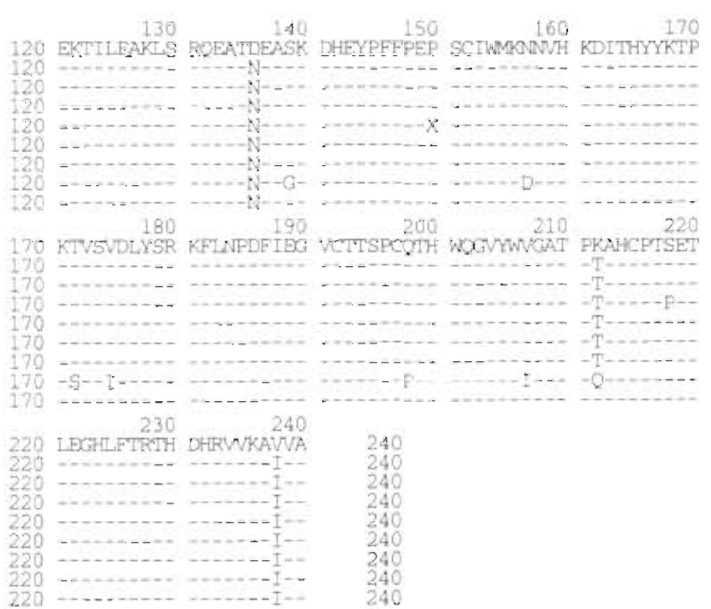

mine how many pools were positive for virus antigen; any such antigenpositive pools could have been regarded as containing infected fish rather than virus as a contaminant from another pool, as it is unlikely that sufficient antigen to produce a positive result in the ELISA would have been transferred from virus-contaminated instruments. Unfortunately, the high background absorbance levels produced by the tissue extracts masked any virus-specific absorbance. As recovery of the virus on thawing the processed samples was variable, it was felt that titrating virus directly from the extract pools would not produce results of any value.

Curiously, 2 pools of tissue extract (nos. 1 and 6) that had been negative for virus in BF-2 cells when tested initially were positive for virus when retested after freeze-thawing. Possible reasons for this are: (1) there was only a low titre of virus in the tissue pools and the small volume of sample taken for testing may have contained virus on one occasion, but not the other; (2) freeze-thawing may have liberated virus from previously incompletely homogenised tissue; (3) freeze-thawing may have selectively destroyed inhibitory components from the tissue extracts; (4) freeze-thawing may have selectively destroyed any defectiveinterfering (DI) virus particles present.

Fig. 3. Sequence alignments of (a) nucleotides 361-720 and (b) the deduced amino acids (residues 121-240) of the glycoprotein gene of the Atlantic herring VHSV isolate (96-43) and other VHSV isolates, derived from their PCR products. (-) indicates the positions of sequence identity compared to the sequence of the $F 1$ isolate. Where the nucleotide sequence could not be adequately resolved due to cross-banding or compressions in the sequence data, the appropriate International Union of Biochemistry abbreviated codes $\mathrm{R}$ (purine) and $Y$ (pyrimidine) were used; $X$ indicates a non-assigned amino acid. The PCR products were obtained from virus harvested from cell culture $(\mathrm{C})$, or from virus in herring extracts $(\mathrm{H})$ 
Fig. 4. Dendrogram showing the genetic relationship of the VHSV isolates based on their PCR products (glycoprotein nucleotide sequences $361-720$ ). The \% sequence identity is indicated at each branching point. The PCR products were obtained from virus in herring extracts $(\mathrm{H})$ harvested from cell culture (C), or from virus

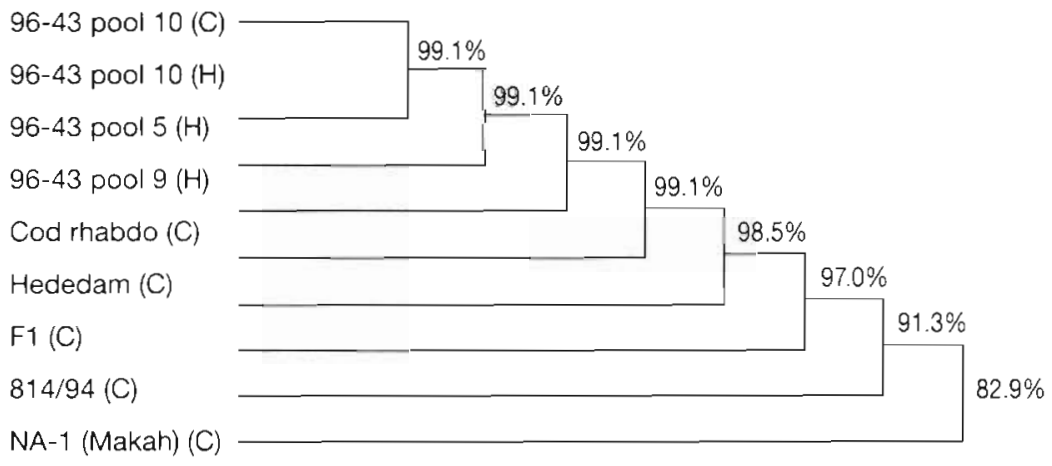

The first reason may also explain why 2 pools (nos. 5 and 10 ) were negative for virus on the second testing occasion

The virus was not isolated in EPC cells, although it was subsequently passaged onto that cell line. This suggests that the EPC cells were more sensitive than BF-2 cells to inhibitory components present in the herring extracts or to the action of DI virus particles, if present. Alternatively, and perhaps more likely, it may have been necessary for the isolate to become cell culture adapted in BF-2 cells before it would replicate in EPC cells; if that were the case, the cell culture adaptation occurred rapidly, as the virus from the first passage in BF-2 cells grew readily in the EPC cells. This reinforces the need to use more than one cell line when attempting to isolate viruses from fish. In a comparison of several VHSV isolates of different origins, isolates from Atlantic cod and turbot (Jensen et al. 1979, Schlotfeldt et al. 1991) only produced a minimal CPE in EPC cells, even on serial passage, whilst producing maximal CPE in other cell lines, including BF-2 cells (Parry \& Dixon unpubl. data); in that comparison, other VHSV isolates produced maximal CPE in the EPC cells. Conversely, Batts et al. (1991) reported that certain VHSV isolates (including those of marine origin) grew to higher titres in EPC cells than in BF-2 cells. The herring isolate in this study also grew to a slightly higher titre in EPC cells after passage from BF-2 cells. Curiously, the titre of virus passaged in EPC cells was practically identical when titrated in BF-2 and EPC cells, but the titre of virus passaged in BF- 2 cells was markedly reduced when titrated in EPC cells compared with titration in the homologous cell line. That might indicate that the virus was becoming more adapted to the BF-2 cell line.

The RT-PCR and sequence data confirmed that the virus isolated in cell culture was VHSV, and that 8 of the 10 herring pools contained virus; the other 2 pools produced equivocal rather than negative results. Only 6 of the pools were positive by isolation in cell culture; the differences between the 2 methods may be as a result of reduced sensitivity of cell culture in this instance, possibly as a result of low levels of infectious virus or the presence of inhibitory material. The variable results between the duplicate RT-PCR amplifications are most likely the result of sub-optimal sample processing (the tissues were processed for cell culture isolation and did not include RNAse inhibitors prior to RNA extraction) and/or because the titre of virus in the tissues was close to the detection limit of the PCR assay (Strømmen \& Stone 1997)

The nucleotide sequence data for the PCR products obtained directly from the herring extracts were $99.1 \%$ similar to each other and to the product obtained from virus grown in cell culture from the herring. This confirmed that the virus isolated in cell culture and the virus in the extract were the same. The slight differences between the sequences of the products from the tissue pools and the cell culture harvest can be attributed to rhabdoviruses having a high rate of mutation during replication, as discussed by Meyers \& Winton (1995). Batts et al. (1993) distinguished North American VHSV isolates from European isolates using DNA probes directed against nucleotide sequences on the $N$ gene, and Stone et al. (1997) extended that division by separating VHSV isolates into 3 genogroups based on the differences in the glycoprotein gene sequence (residues 361-720). Genogroup I comprised VHSV isolates from North America, genogroup II comprised marine isolates from around Scotland, and genogroup III comprised European marine and freshwater VHSV isolates. The Atlantic herring VHSV isolate showed $82.9 \%$ nucleotide sequence similarity to NA-1 (Makah), a representative of genogroup I, $91.3 \%$ similarity to $814 / 94$, a representative of genogroup II, and $97 \%$ similarity to the F1 isolate, a representative of genogroup III. On that basis the Atlantic herring isolate can be best classified as a member of genogroup III. The deduced amino acid sequences were well conserved between isolates, which is consistent with previous observations (Stone et al. 1997), and possibly reflects constraints placed on the glycoprotein sequence by protein function. 
The herring from which the virus was isolated showed no obvious external or internal signs of disease, but the majority of the VHSV isolates from marine fish (with the exception of those from anadromous salmonids in North America) originated from fish with pathologies (often evident in the skin) (Jensen et al. 1979, Schlotfeldt et al. 1991, Ross et al. 1994, Smail 1995, Meyers \& Winton 1995, unpubl, data of D. Smail cited by Munro 1996). Whether the virus caused these pathologies is not known, and there are only few data on the experimental pathogenicity of the marine VHSV isolates. The North American isolates, all of marine or anadromous fish origin, are reportedly not virulent for salmonids (Winton et al. 1991, Meyers et al. 1994), with 2 exceptions: a Pacific cod isolate produced $20 \%$ mortality in rainbow trout (unpubl. data referred to by Meyers et al. 1994) and a Pacific herring isolate was pathogenic to Atlantic salmon Salmo salar after intraperitoneal injection (unpubl. data of G. Traxler \& D. Keiser cited by Meyers \& Winton 1995). The latter isolate produced mortalities in Pacific herring and in shiner perch Cymatogaster aggregata after both bath infection or injection. The Scottish turbot isolate killed $70 \%$ of bath-infected turbot (P. F. Dixon \& S. Avery unpubl. data). Our data show a strong genetic link between the Atlantic herring VHSV isolate and the 'cod rhabdo' and Hededam isolates (99.1 and 98.5\% sequence similarity, respectively). The Hededam isolate is virulent for rainbow trout under experimental conditions (Jørgensen 1980), but the Atlantic herring isolate was not virulent for the population of rainbow trout tested in this study. Jørgensen (1992) reported that the isolate from Danish cod ('cod rhabdo') was avirulent for $2 \mathrm{~g}$ rainbow trout exposed to the virus by bath, and our trial with that isolate using $4.8 \mathrm{~g}$ fish gave a similar result. It will be of importance to determine the virulence of the Atlantic herring isolate for herring and other species, and so determine the risk that the isolate poses to marine and freshwater fish stocks.

The diseased Atlantic cod from which the 'cod rhabdo' was isolated were caught in Danish coastal waters off Nykøbing (Jensen et al. 1979), which is on the island of Falster to the east of Jutland. This may be significant, as the nursery area of Atlantic herring extends from the coast of The Netherlands to eastern Jutland (Daan et al. 1990). Therefore, it is possible that VHSV could be transmitted between cod and herring (although in which direction is unknown) in such an area. Herring are the food of many marine species and the further spread of VHSV in the marine environment could be by predation on infected herring. Such a scenario has been postulated for Pacific herring in North America (Meyers et al. 1994, Meyers \& Winton 1995). However, in European marine waters, where different genotypes of the virus exist, there may be different host sources of the virus, or different populations of virus in herring stocks. Of further interest is the Denmark/herring link in postulating the transfer of VHSV from the marine to the freshwater environment. Rasmussen (1965) summarised the data to that date for Egtved (VHS) disease. It was described as being recorded initially in eastern Jutland, and Rasmussen discussed possible aetiologies for the disease. He cited work by Lauridsen (1958), who suggested that the disease was caused by a deficiency of vitamins $B_{1}$ and $E$ '.... which would be a consequence of the fact that herring is the predominant food used in Danish trout hatcheries' (Rasmussen 1965). If those herring had been infected with VHSV, it is feasible that over time an isolate that was virulent for rainbow trout could have been introduced, or could have emerged after passage through rainbow trout. Thus, there are possible links between VHSV in herring and VHSV in cod, and geographic location, and also between herring and rainbow trout. That link between VHSV in herring and VHSV in rainbow trout is purely circumstantial, but it could explain the origin of the disease in freshwater. Raw marine fish are still used as a food source for some aquaculture fish species, and the risk of disease transmission from such a practice is high. Indeed, the turbot from Scotland from which VHSV was isolated had been fed on certain occasions with raw, minced, marine fish (mainly haddock) as an alternative to a commercial diet (Munro 1996). Alternative food sources or food processing methods should be developed to minimise the transmission of fish diseases by that route.

Further studies on the host range and virulence of individual VHSV isolates, together with more detailed genetic analysis of those isolates, may provide further information on the epidemiology of VHS disease

Acknowledgement. Mr Lee Parry was on an industrial placement at FDL, sponsored by MAFF (contract CSA 3321).

\section{LITERATURE CITED}

Anonymous (1992) Commission Decision 92/532/EC. Sampling and testing procedures for VHS and IHN monitoring. Off J Eur Comm L 337:18-27

Batts WN, Arakawa CK, Bernard J, Winton JR (1993) Isolates of viral hemorrhagic septicemia virus from North America and Europe can be detected and distinguished by DNA probes. Dis Aquat Org 17:67-71

Batts WN, Traxler GS, Winton JR (1991) Factors affecting the efficiency of plating for selected fish rhabdoviruses. In: Proc Second Int Symp Viruses of Lower Vertebrates. Oregon State University, Corvallis, p 17-24

Brunson R, True $K$, Yancey J (1989) VHS virus isolated at Makah National Fish Hatchery. Fish Health Sect Am Fish Soc Newslett 17:3-4

Bucke D, Vethaak D, Lang D, Mellergaard S (1996) Common diseases and parasites of fish in the North Atlantic: train- 
ing guide for identification. ICES Techniques in Marine Environmental Sciences No. 19, Copenhagen

Daan N. Bromley PJ, Hislop JRG, Nielsen NA (1990) Ecology of North Sea fish. Neth J Sea Res 26:343-386

Dixon PF, Hill BJ (1983) Rapid detection of infectious pancreatic necrosis virus (IPNV) by the enzyme-linked immunosorbent assay (ELISA). J Gen Virol 64:321-330

Higgins DG. Sharp PM (1988) CLUSTAL: a package for performing multiple sequence alignments on a microcomputer. Gene 73:237-244

Hill BJ, Underwood BO, Smale CJ, Brown F (1975) Physicochemical and serological characterization of five rhabdoviruses infecting fish. J Gen Virol 27:369-378

Hopper K (1989) The isolation of VHSV from chinook salmon at Glenwood Springs, Orcas Island, Washington. Fish Health Sect Am Fish Soc Newslett 17:1

Jensen MH (1965) Research on the virus of Egtved disease. Ann NY Acad Sci 126:422-426

Jensen NJ, Bloch B, Larsen JL (1979) The ulcus-syndrome in cod (Gadus morhua). III. A preliminary virological report. Nord Veterinæermed 31:436-442

Jørgensen PEV (1980) Egtved virus: the susceptibility of brown trout and rainbow trout to eight virus isolates and the significance of the findings for the VHS control. In: Ahne W (ed) Fish diseases. Third COPRAQ-Session. Springer Verlag, Berlin, p 3-7

Jørgensen PEV (1992) Recent advances in surveillance and control of viral haemorrhagic septicaemia (VHS) of trout. Proc OJI Int Symp Salmonid Diseases. Hokkaido University Press, Sapporo, Japan, p 60-71

Jørgensen PEV, Olesen NJ (1987) Cod ulcus syndrome rhabdovirus is indistinguishable from the Egtved (VHS) virus. Bull Eur Assoc Fish Pathol 7:73-74

Lauridsen $O$ (1958) Undersøgelser over den sâkaldte arredvirussygdom hos regnbueørred. Nord Veterinærmed 10: $553-576$

Lorenzen N, Olesen NJ, Jørgensen PEV (1993) Antibody response to VHS virus proteins in rainbow trout. Fish Shellfish Immunol 3:461-473

Meyers TR, Short S, Lipson K, Batts WN, Winton JR, Wilcock J, Brown E (1994) Association of viral hemorrhagic septicemia virus with epizootic hemorrhages of the skin in Pacific herring Clupea harengus pallasi from Prince William Sound and Kodiak Island, Alaska, USA. Dis Aquat Org 19:27-37

Meyers TR, Sullivan J, Emmenegger E, Follett J, Short S Batts WN, Winton JR (1991) Isolation of viral hemorrhagic septicaemia virus from Pacific cod Gadus macrocephalus in Prince William Sound, Alaska. In: Proc Second Int Symp Viruses of Lower Vertebrates. Oregon State University, Corvallis, p 83-91

Responsible Subject Editor: JoAnn Leong, Corvallis, Oregon, USA
Meyers TR, Winton JR (1995) Viral hemorrhagic septicemia virus in North America. Annu Rev Fish Dis 5:3-24

Munro ALS (1996) First recorded outbreak of viral haemorrhagic septicaemia (VHS) in GB and subsequent actions to contain, eradicate and investigate the origins of the infection. Scottish Office Agriculture, Environment and Fisheries Department, Scottish Aquaculture Research Report No. 3, Aberdeen

Rasmussen CJ (1965) A biological study of the Egtved disease (INuL). Ann NY Acad Sci 126: 427-460

Ross K, McCarthy U, Huntly PJ, Wood BP, Stuart D, Rough EI, Smail DA, Bruno DW (1994) An outbreak of viral haemorrhagic septicaemia (VHS) in turbot (Scophthalmus maximus) in Scotland. Bull Eur Assoc Fish Pathol 14:213-214

Sanger F, Nicklen S, Coulson AR (1977) DNA sequencing with the chain-termination inhibitors. Proc Nat Acad Sci USA 75:5453-5467

Schlotfeldt HJ, Ahne W, Jorgensen PEV, Glende W (1991) Occurrence of viral haemorrhagic septicaemia in turbot (Scophthalmus maximus) - a natural outbreak. Bull Eur Assoc Fish Pathol 11:105-107

Smail DA (1995) Isolation and identification of viral haemorrhagic septicaemia (VHS) virus from North Sea cod (Gadus morhua L.). ICES Int Counc Explor Sea CM 1995/F:15 (mimeo)

Stone DM, Way K, Dixon PF (1997) Nucleotide sequence of the glycoprotein gene of viral haemorrhagic septicaemia (VHS) viruses from different geographical areas: a link between VHS in farmed fish species and viruses isolated from North Sea cod (Gadus morhua L.). J Gen Virol 78: $1319-1326$

Strommen HK, Stone DM (1997) Detection of viral haemorrhagic septicaemia (VHS) virus in fish tissues by seminested polymerase chain reaction (PCR). Proc Symp Methodol Fish Dis Res (in press)

Traxler GS, Kieser D (1994) Isolation of the North American strain of viral hemorrhagic septicaemia virus (VHSV) from herring (Clupea harengus pallasi) in British Columbia. Fish Health Sect Am Fish Soc Newslett 22:8

Way K (1996) Development of a rapid dipstick-format field test for VHS virus. Bull Eur Assoc Fish Pathol 16:58-62

Way K, Dixon PF (1988) Rapid detection of VHS and IHN viruses by the enzyme-linked immunosorbent assay (ELISA). J Appl Ichthyol 4:182-189

Wheeler A (1992) A list of the common and scientific narnes of fishes of the British Isles. J Fish Biol 41 (Suppl A):1-37

Winton JR, Batts WN, Deering RE, Brunson R, Hopper K, Nishizawa T, Stehr C (1991) Characteristics of the first North American isolates of viral hemorrhagic septicemia virus. In: Proc Second Int Symp Viruses of Lower Vertebrates. Oregon State University, Corvallis, p 43-50

Manuscript received: February 27, 1997

Revised version accepted: April 29, 1997 